Special issue of the 3rd International Conference on Computational and Experimental Science and Engineering (ICCESEN 2016)

\title{
Characterization of Alumina-Titania Coatings Produced by Atmospheric Plasma Spraying on 304 SS Steel
}

\author{
M. Djendel*, O. Allaoui and R. Boubahya \\ Laboratoire Génie des Procédés, Université de Laghouat, BP 37G, Laghouat, Algeria
}

\begin{abstract}
The alumina-titania coatings produced by atmospheric plasma spraying are being developed for a wide variety of applications that require resistance to wear, erosion, cracking, and spallation. Consideration of parameters setting will develop reliable coatings with high performance properties for demanding coating application. $\mathrm{Al}_{2} \mathrm{O}_{3}-$ $3 \mathrm{wt} \% \mathrm{TiO}_{2}$ was used as the main coating. $\mathrm{Ni} 20 \% \mathrm{Cr}_{6} \mathrm{Al}$ powder was used as bond coat coating onto AISI 304 stainless steel substrate using Sulzer-Metco plasma spray system 9MC equipment.
\end{abstract}

DOI: 10.12693/APhysPolA.132.538

PACS/topics: alumina-titania coatings, atmospheric plasma spraying, 304 stainless steel, process parameters, SEM, microstructure

\section{Introduction}

Plasma-sprayed ceramic coatings are widely used for structural applications in order to improve resistances to wear, friction, corrosion, and oxidization $[1,2]$. In atmospheric plasma spraying (APS), one of many plasma spray methods [3], a coated layer is formed on a substrate surface by spraying melted powders onto a substrate at a high speed using a high-temperature plasma jet $[4,5]$. Powder grains are transported within a carrier gas at high temperature and high speed, injected into plasma jet. The melting powder is transferred to the substrate surface being coated and after impact; lamellar layer formation occurs [6-8]. Alumina $\left(\mathrm{Al}_{2} \mathrm{O}_{3}\right)$ and mixed alumina with titania are widely used in plasma sprayed as coating materials. The high hardness of alumina properties contributes to wear resistant coating and electrical insulation properties. Alumina is also highly thermal conductivity insulated for any substrate. Alumina with approximately $3 \mathrm{wt} \%$ titania is used extensively as wear resistance coating. The different coating microstructures and properties are depending on the spray technique, powder properties and spray parameters of the coating [911]. The coating conditions such as porosity, closed pores and unmelted particles are always the cause of defects in coatings. There are advanced tests or performance tests techniques of plasma sprayed ceramic coatings in order to determine the coating properties such as mechanical tests. A number of works for different purposes were also performed on different types of steel [12-14].

In the present work, alumina- 3 wt\% titania coatings are deposited on AISI 304 stainless steel substrates with

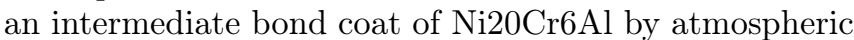
plasma spraying. The effects of the plasma variables setting such as the powder flow rate, current and standoff-distance on the microstructure and adhesion strength were investigated.

*corresponding author; e-mail: m.djendel@lagh-univ.dz

\section{Experimental procedure}

AISI 304 stainless steel substrate with $2 \mathrm{~mm}$ thickness and $25 \mathrm{~g} / \mathrm{cm}^{2}$ density was selected as substrate in this study. The selected plate is a technical delivery conditions for general purpose structural stainless steel which is used to build ship, bridge, etc. Ceramic feedstock $\mathrm{Al}_{2} \mathrm{O}_{3}-3$ wt\% $\mathrm{TiO}_{2}$ was used as the main coating and (Ni-20Cr)6Al powder was used as bond coating with an average of about $50 \mu \mathrm{m}$ thick bond layer on the surface of the substrates to obtain better performance of the plasma sprayed $\mathrm{Al}_{2} \mathrm{O}_{3}-3 \mathrm{TiO}_{2}$. Table I show the powder specifications used for main coating.

TABLE I

Coating powder specifications.

\begin{tabular}{c|c|c|c|c|c|c}
\hline \hline Elements & $\mathrm{Al}_{2} \mathrm{O}_{3}$ & $\mathrm{TiO}_{2}$ & $\mathrm{SiO}_{2}$ & $\mathrm{Fe}_{2} \mathrm{O}_{3}$ & $\mathrm{MgO}$ & Others \\
\hline $\mathrm{Al}_{2} \mathrm{O}_{3}-3 \mathrm{wt} \% \mathrm{TiO}_{2}$ & 94.5 & 2.66 & 2.11 & 0.26 & 0.26 & 0.24
\end{tabular}

$\mathrm{Al}_{2} \mathrm{O}_{3}-3 \mathrm{wt} \% \mathrm{TiO}_{2}$ coating was produced onto AISI 304 stainless steel substrate using Sulzer-Metco atmospheric plasma spray system 9MC Equipment, using argon and hydrogen as the plasma arc gases and argon as the powder carrier gas. This paper discusses the experimental and testing performance analysis of the coating which is prepared based on three varied process parameters (current, powder flow rate, and stand-off-distance). Table II shows the parameters setting used for bond coat, top coat coating processes, and also the varied setting process parameters for the top coat (i.e. current, powder feed rate, and stand-off-distance).

\section{Result and discussion}

The parameters of spraying have an influence on mechanical properties like porosity, microhardness, and the microstructure. Microstructural characterization was carried out with scanning electron microscopy (SEM) $[5,15]$. 
TABLE II are $11.19 \mathrm{MPa}(\mathrm{P} 2)$ and $5.15 \mathrm{MPa}$ (P3). The highest

Parameters setting used for bond coat, top coat.

\begin{tabular}{c|c|c|c}
\hline \hline No. & Variables parameters & $\begin{array}{c}\text { Bond } \\
\text { coat } \\
\text { coating }\end{array}$ & $\begin{array}{c}\text { Top } \\
\text { coat } \\
\text { coating }\end{array}$ \\
\hline 1 & primary gas (argon and hydrogen), PSI & 25 & 25 \\
2 & carrier gas (argon), PSI & 90 & $90-110$ \\
3 & voltage [V] & 65 & 65 \\
4 & current [A] & 550 & $90-110$ \\
5 & powder flow rate [g/min] & 25 & $22-26$ \\
6 & stand-off-distance [mm] & 90 & $75-90$
\end{tabular}

\subsection{Microstructure of coatings}

SEM micrograph of $\mathrm{Al}_{2} \mathrm{O}_{3}-3 \mathrm{wt} \% \mathrm{TiO}_{2}$ powder coating is shown in Fig. 1a. From the cross-sectional microstructures, it can be seen that coatings consist of the lamella built up from the molten droplets impinging on the substrate. The coating (Fig. 1a) has a layered microstructure, typical of plasma sprayed coatings, which is the result of full melting of the ceramic feedstock powder and its solidification as "splats" on the substrate. There were 3 different layers shown in Fig. 1b, namely ceramic layer, intermediate layer and substrate. The coating layers were on average $200 \mu \mathrm{m}$ and bond layers $(\mathrm{Ni}-20 \% \mathrm{Cr}$ ) $6 \mathrm{Al}$ were approximately $50 \mu \mathrm{m}$ thick. Pores were observed in all coating layers.

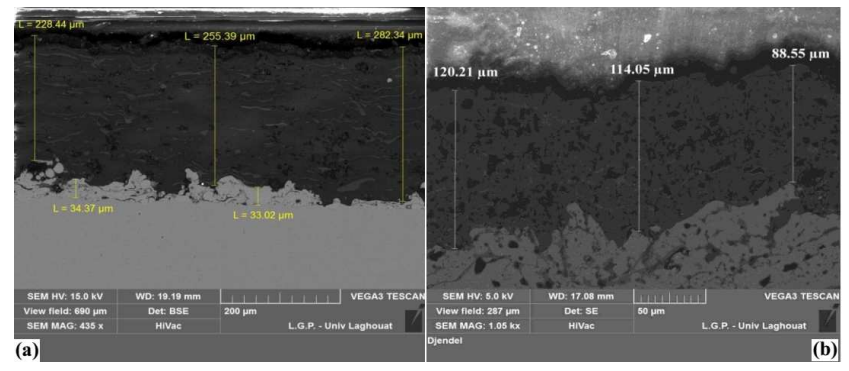

Fig. 1. (a) SEM micrograph of $\mathrm{Al}_{2} \mathrm{O}_{3}-3$ wt\% $\mathrm{TiO}_{2}$ powder coating, (b) 3 different layers, namely ceramic layer, intermediate layer, and substrate.

\subsection{Effect of APS parameters on mechanical properties}

\subsubsection{Adhesion strength}

Adhesion strength is one of the major requirement test technique being applied for hard coating technology. The composite specimen was loaded in tension until it is failed perpendicular to the coating surface and the maximum load before failed was measured to calculate the adhesion strength.

\subsubsection{Adhesion strength and stand-off-distance}

The graph of adhesion strength versus stand-offdistance at $75 \mathrm{~mm}$ and $90 \mathrm{~mm}$ of $\mathrm{Al}_{2} \mathrm{O}_{3}-3 \mathrm{wt} \% \mathrm{TiO}_{2}$ coatings is shown in Fig. 2, the highest and lowest adhesion strengths of coating at spraying distances of $75 \mathrm{~mm}$ and lowest adhesion strengths of coating at spraying distance of $90 \mathrm{~mm}$ are $8.51 \mathrm{MPa}(\mathrm{P} 6)$ and $6.56 \mathrm{MPa}(\mathrm{P} 7)$. The highest adhesion strength was identified at the setting parameters for the powder flow rate of $26 \mathrm{~g} / \mathrm{min}$ and current setting at $650 \mathrm{~A}$. At the specified parameters setting, increasing stand-off-distance from $75 \mathrm{~mm}$ to $90 \mathrm{~mm}$ reduced the adhesion strength of coating. Scientifically, optimum stand-off-distance is important to ensure good adherence of coating bonding. Too short spraying distance will produce lower adherence due to overheating and resulting internal stress inside the coating. In contrast, too long spraying distance will decrease the adherence bonding due to cooling and deceleration of the particles flying in the plasma beam [16].

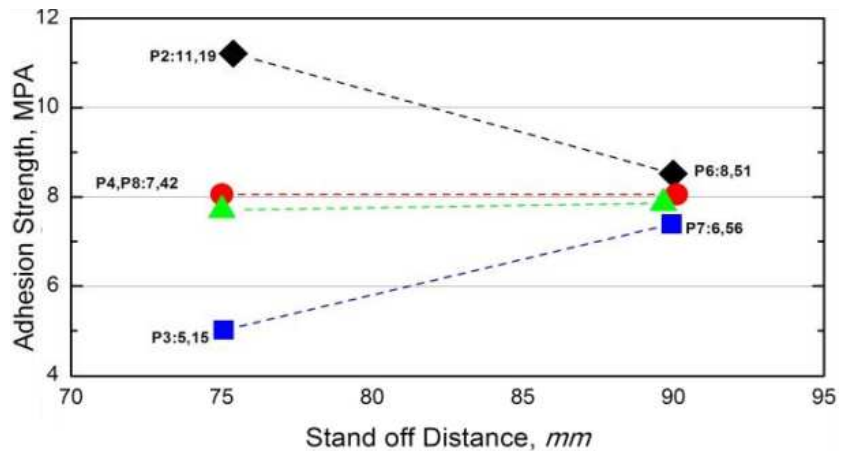

Fig. 2. Adhesion strength vs. stand-off distance.

\subsubsection{Adhesion strength and powder flow rate}

The graph of adhesion strength versus powder flow rate at $22.5 \mathrm{~g} / \mathrm{min}$ and $26 \mathrm{~g} / \mathrm{min}$ for the $\mathrm{Al}_{2} \mathrm{O}_{3}-3 \mathrm{wt} \% \mathrm{TiO}_{2}$ coating is shown in Fig. 3, the highest and lowest adhesion strengths of coating for the powder flow rates of $22.5 \mathrm{~g} / \mathrm{min}$ are $8.21 \mathrm{MPa}(\mathrm{P} 1)$ and $4.91 \mathrm{MPa}(\mathrm{P} 3)$. The highest and lowest adhesion strengths of coating for the powder flow rates of $26 \mathrm{~g} / \mathrm{min}$ are $11.67 \mathrm{MPa}(\mathrm{P} 2)$ and $7.55 \mathrm{MPa}(\mathrm{P} 4)$. The graph pattern shows that increasing powder flow rate will increase the adhesion strength of coating. The coating specimens at spraying distance of $75 \mathrm{~mm}$ and current setting of 650 A presented the highest adhesion strength of coating.

\subsubsection{Adhesion strength and current}

The graph of adhesion strength versus current is shown in Fig. 4, at setting of $550 \mathrm{~A}$ and $650 \mathrm{~A}$. The highest and lowest adhesion strengths for the current setting of $550 \mathrm{~A}$ are 7.42 $\mathrm{MPa}$ (P4 and P8) and 5.1 MPa (P3). The highest and lowest adhesion strengths for the current setting of $650 \mathrm{~A}$ are $11.48 \mathrm{MPa}(\mathrm{P} 2)$ and $8.2 \mathrm{MPa}$ (P5). It can be observed that the highest adhesion strength was identified at the spraying distance of $75 \mathrm{~mm}$ and powder flow rate of $26 \mathrm{~g} / \mathrm{min}$. Graph pattern shows that increasing current will increase the adhesion strength of coating. At the specified setting parameters, the specimen set at 650 A represents the highest adhesion strength compared to the other specimens. By increasing the current, the 


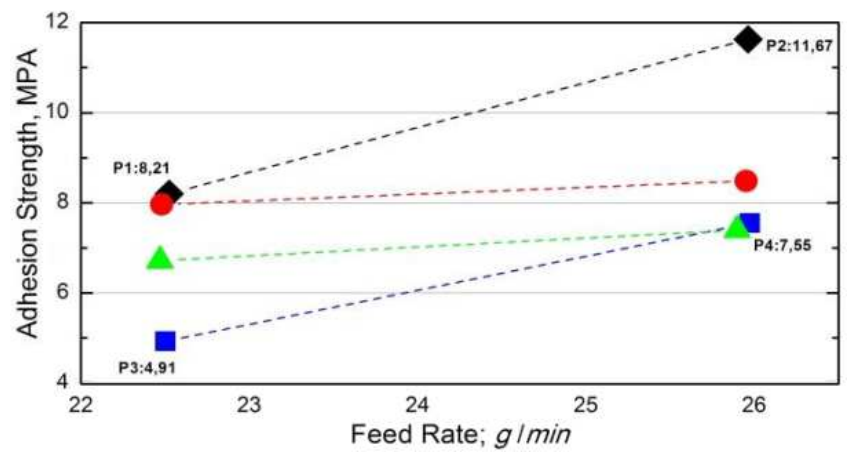

Fig. 3. Adhesion strength vs. powder flow rate.

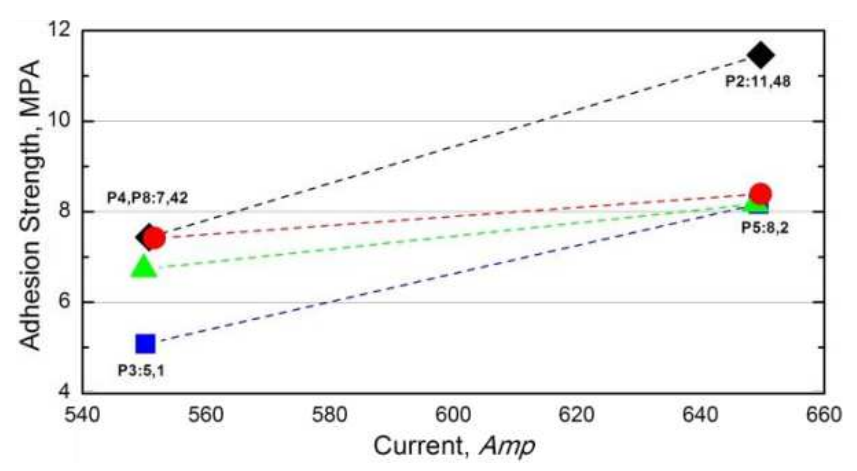

Fig. 4. Adhesion strength vs. current.

temperature of process increased, therefore, more particles were melted, and hence high adhesion strength of coatings produced [10].

\section{Conclusion}

- Alumina-titania coatings are deposited on stainless steel substrates with an intermediate bond coat of Ni20Cr6Al by atmospheric plasma spraying and these bond coatings exhibit desirable coating characteristics like adhesion strength. The parameters setting such as powder flow rate, current, and stand-off-distance has provided evidence to directly influence the properties and performance of $\mathrm{Al}_{2} \mathrm{O}_{3}-3 \mathrm{wt} \% \mathrm{TiO}_{2}$ coating. Adhesion strength varied depending on the process parameters setting. Increasing the parameters setting of powder flow rate and current setting improved the adhesion strength of $\mathrm{Al}_{2} \mathrm{O}_{3}-3$ wt\% $\mathrm{TiO}_{2}$ coating.

- Results show the appearance of microdefects such as microcracks, pores, unmolten particles, and semi-molten ones, etc. in coatings.

\section{References}

[1] A. Günen, Acta Phys. Pol. A 130, 217 (2016).

[2] İ.H. Karahan, Acta Phys. Pol. A 130, 286 (2016).

[3] M. Cadenas, R. Vijande, H.I. Montes, I.M. Siena, Wear 212, 244 (1997).

[4] E.P. Song, J. Ahn, S. Lee, N.J. Kim, Surf. Coat. Technol. 201, 1309 (2006).

[5] I.N. Qureshi, M. Shahid, A.N. Khan, Acta Phys. Pol. A 128, B-314 (2015).

[6] M. Bounazef, S. Guessasma, G. Montavon, C. Coddet, Mater. Lett. 58, 2451 (2004).

[7] S. Kumar, V. Selvarajan, P.V.A. Padmanabhan, K.P. Sreekumar, Surf. Coat. Technol. 201, 1267 (2006).

[8] A.-F. Kanta, M.-P. Planche, G. Montavon, C. Coddet, Surf. Coat. Technol. 204, 1542 (2010).

[9] P. Fauchais, A. Vardelle, B. Dussoubs, in: Thermal Spray 2001: New Surfaces for a New Millennium, Eds. C.C. Berndt, K.A. Khor, E.F. Lugscheider, ASM International, Materials Park (OH) 2001, p. 1.

[10] L. Zhao, K. Seemann, A. Fischer, E. Lugscheider, Surf. Coat. Technol. 168, 186 (2003).

[11] A.R.M. Sahab, N.H. Saad, S. Kasolang, J. Saedon, Proced. Eng. 41, 1689 (2012).

[12] I. Akkurt, A. Calik, H. Akyıldırım, Nucl. Eng. Des. 241, 55 (2011).

[13] A. Calik, S. Akbunar, N. Ucar, N. Yilmaz, S. Karakas, I. Akkurt, Nucl. Technol. Radiat. Protect. 29, 186 (2014).

[14] I. Akkurt, Ann. Nucl. En. 36, 1702 (2009).

[15] S. Kirtay, Acta Phys. Pol. A 128, B-90 (2015).

[16] İ.H. Karahan, Acta Phys. Pol. A 128, B-432 (2015). 